\title{
Living kidney donation
}

\author{
Ann Bugeja MD, Edward G. Clark MD MSc
}

Cite as: CMAJ 2017 August 14;189:E1041. doi: 10.1503/cmaj.170304

\section{Benefits of kidney transplantation from living donors are \\ 1. improved compared with dialysis}

Kidney transplantation from living donors has improved survival rates, better quality of life and lower costs for health care for eligible patients with end-stage kidney disease than dialysis..$^{1,2}$ Kidney transplants from living donors also last about 25\% longer (typically 20-25 years) and are associated with better overall survival than transplants from deceased donors. ${ }^{1}$

\section{Living kidney donors remain at low risk of end-stage kidney disease $^{3}$}

Potential donors undergo extensive evaluation to assess surgical and long-term risks (Appendix 1, www.cmaj.ca/lookup/suppl/doi:10.1503/ cmaj.170304/-/DC1). The risk of death is 3 in 10000 donor nephrectomies. ${ }^{2}$ Perioperative complications, such as infection or bleeding, occur in fewer than $10 \%$ of these procedures. ${ }^{2}$ After 15 years, end-stage kidney disease is diagnosed in about $0.3 \%$ of donors. ${ }^{3}$ Life insurance premiums are unlikely to be affected. ${ }^{4}$

\section{3}

\section{About 400 Canadians become living kidney donors annually ${ }^{1}$}

Most living kidney donors know their recipient but are not necessarily related or share the same blood group. Fewer than $3 \%$ of living kidney donors are anonymous and do not have an intended recipient. ${ }^{1}$ For all potential living kidney donors, assessment of eligibility is started after they have contacted a living kidney donor transplant program (Box 1). There are over 3000 Canadians with end-stage kidney disease on the transplant waiting list. $^{1}$

Preeclampsia and gestational hypertension are more likely to develop in living kidney donors ${ }^{5}$

The absolute increased risk of preeclampsia and gestational hypertension, compared with nondonors, was 3\% in an Ontario study that included 85 living kidney donors (131 postdonation pregnancies) who were followed for up to 20 years. ${ }^{5}$ No significant differences were found for other important maternal and fetal outcomes. Women can be reassured that risks to pregnancies after kidney donation are minimal.

Annual follow-up is recommended after kidney donation ${ }^{2}$

Living kidney donors may have an increased risk of hypertension and proteinuria after donation. ${ }^{2}$ For early identification of these modifiable risk factors for progressive loss of kidney function, annual monitoring of blood pressure, serum creatinine level and urine albumin:creatinine ratio is suggested after donation. ${ }^{2}$
Box 1: Supplementary resources for people interested in living kidney donation

General information from the Kidney Foundation of Canada/La Fondation canadienne du rein regarding kidney transplantation, including living kidney donation, is available at:

- English: https://www.kidney.ca/organ-donation

- Français: https://www.kidney.ca/dons-dorganes

Contact information for all living donor kidney transplantation programs in Canada is available at:

- English: https://blood.ca/en/organs-tissues/ becoming-live-kidney-donor

- Français: https://blood.ca/fr/organes-tissus/ donner-rein-son-vivant

This site also provides information regarding the Canadian Blood Services/La Société canadienne du sang Kidney Paired Donation Program for immunologically incompatible living kidney donors and their intended recipients.

\section{References}

1. Organ donation and transplantation in Canada - system progress report 2006-2015. Ottawa: Canadian Blood Services; 2016. Available: https://professionaleducation.blood.ca/en/organs-tissues (accessed 2017 Mar. 16).

2. Bailey P, Edwards A, Courtney AE. Living kidney donation. BMJ 2016;354:i4746.

3. Mjoen G, Hallan S, Hartmann A, et al. Long-term risks for kidney donors. Kidney Int 2014;86:162-7.

4. Yang RC, Young A, Nevis IF, et al. Life insurance for living kidney donors: a Canadian undercover investigation. Am J Transplant 2009;9:1585-90.

5. Garg AX, McArthur E, Lentine KL; Donor Nephrectomy Outcomes Research (DONOR) Network. Gestational hypertension and preeclampsia in living kidney donors. N Engl J Med 2015;372:1469-70.

\section{Competing interests: None declared.}

This article has been peer reviewed.

Affiliation: Division of Nephrology, Department of Medicine, The Ottawa Hospital and University of Ottawa, Ottawa, Ont.

Correspondence to: Ann Bugeja, abugeja@toh.ca 